\title{
HERITABILITY, PHENOTYPIC AND GENETIC CORRELATIONS OF THE GROWTH INTENSITY AND MEAT YIELD OF PIGS
}

\author{
Č. Radović ${ }^{1}$, M. Petrović ${ }^{2}$, B. Živković ${ }^{1}$, D. Radojković ${ }^{2}$, N. Parunović ${ }^{3}$, \\ N. Brkić ${ }^{4}$, N. Delić \\ ${ }^{1}$ Institute for Animal Husbandry, 11080, Belgrade-Zemun, Republic of Serbia \\ ${ }^{2}$ Faculty of Agriculture, University of Belgrade, 11080, Belgrade - Zemun, Republic of Serbia \\ ${ }^{3}$ Institute of Meat Hygiene and Technology, 11000, Belgrade, Republic of Serbia \\ ${ }^{4}$ Ministry of Agriculture, Forestry and Water Management - Directorate for Water, 11000, Belgrade, \\ Republic of Serbia \\ Corresponding author: cedomirradovic.izs@gmail.com \\ Original scientific paper
}

Abstract: The five year study included two genotypes of gilts of performance tested gilts, Swedish landrace and crosses $F_{1}$ generation SLxLY. Of total number $(\mathrm{n}=3600), 1709$ animals were genotype SL and 1891 animals were genotype SLxLY. Measuring of back fat thickness in the loin part (FT1), between 3rd and 4th lumbar vertebrae, $7 \mathrm{~cm}$ laterally to the back line; back fat thickness (FT2) and depth of the musculus longissimus dorsi (MLD) between the 3rd and 4th rib from the rear, $7 \mathrm{~cm}$ laterally to the back line. Assessment of meat yield was done using the ultrasonograph apparatus Piglog 105. In regard to meat yield indicators, medium heritability values were established for FT $1 \mathrm{~h}^{2}=0.461$, and high values for FT2 $h^{2}=0.639$, and for meat yield $h^{2}=0.633$. Low heritability was established for depth of MLD $\left(h^{2}=0.105\right)$, life daily gain $\left(h^{2}=0.110\right)$ and age at the end of test $\left(h^{2}=0.103\right)$. Established phenotypic correlations between fat thickness FT1 and FT2 were strong $\left(\mathrm{r}_{\mathrm{p}}=0.638\right)$; between fat thickness and meat yield very strong $\left(\mathrm{r}_{\mathrm{p}}=-0.880\right.$ to -0.895$)$, and between fat thickness and MLD very weak and negative $\left(\mathrm{r}_{\mathrm{g}}=-0.103\right.$ to -0.216). Genetic correlations were stronger than phenotypic, so between fat thickness FT1 and FT2 the correlation was complete/full ( $\left.\mathrm{r}_{\mathrm{g}}=0.930\right)$, also between fat thickness and meat yield $\left(\mathrm{r}_{\mathrm{g}}=-0.979\right.$ to -0.982$)$, whereas the correlation between fat thickness and MLD was strong and negative $\left(\mathrm{r}_{\mathrm{g}}=-0.627\right.$ to -0.653$)$. Heritability values for fat thickness and meat yield show that these traits have high level of heritability and are transfered to the progeny, whereas the level and strength of their dependance show that by decreasing the fat thickness positive influences is exhibited on meat yield, and that by increasing of depth of MLD also the meat yield is increased.

Key words: gilt; genotypes; backfat thickness; lean meat content; Piglog 


\section{Introduction}

Intensity of growth, food utilization and meat yield are of great importance in breeding and selection. Considering that quantitative traits and their expression are under the influence of several genes, they are under strong influence of environment factors. This shows the significance of accurate and as precise possible assessment of these traits, as well as of the breeding value of the animal. The rate of selection progress depends on the intensity of selection, heritability $\left(h^{2}\right)$ or accuracy in the evaluation of the animal's breeding value and average time interval between generations, i.e. average age of parents at birth of their progeny. Heritability coefficients for growth traits and carcass side quality are medium to high (Lo et al., 1992; Knapp et al., 1997; Hermesch et al., 2000; Chan et al., 2002; Gorjanc et al., 2003; Radović et al., 2003; Petrović et al., 2006). In the study of five breeds at the age of 180 days and average body weight of $110 \mathrm{~kg}$, SzyndlerNedza et al. (2010) have established the heritability for daily gain in boars of 0.070 for Puławska breed to 0.578 for Pietrain breed, whereas for lean percentage they have established lower heritability values of 0.013 for Puławska and 0.453 for Duroc breeds. In the same study, for gilts, established values $h^{2}$ for daily gain ranged from 0.079 to 0.585 , and for lean percentage, from 0.032 to 0.303 . Groeneveld and Peškovičova (1999), in their evaluation of the breeding value of gilts and boars in Slovakia, have established slightly lower heritability values for daily gain in the test $(0.13$ to 0.19$)$. Authors state that the reason for low heritability values is in the structure of the data base.

In light of above mentioned, the need for continuous investigation and monitoring of the growth intensity and meat yield indicators is apparent, in order to determine as precisely and accurately possible the heritability, genetic and phenotypic correlations, since most of quantitative traits are influenced by numerous genes on different loci.

\section{Material and Methods}

Study of performance tested gilts was done during the period 2007 to 2001 . In regard to test years, the distribution of gilts was following: $\mathrm{n}_{2007}=682, \mathrm{n}_{2008}=875$, $\mathrm{n}_{2009}=962, \mathrm{n}_{2010}=697$ and $\mathrm{n}_{2011}=384$ gilts. Investigation included two genotypes Swedish Landrace and crosses of $F_{1}$ generation SLxLY (the first one designated is the dam). Of total number of animals ( $\mathrm{n}=3600)$ included in the study, 1709 animals were genotype SL and 1891 animals of genotype SLxLY. Measuring of the back fat thickness and depth of the musculus longissimus dorsi (MLD) was done on animals of body weight of 90 to $110 \mathrm{~kg}$, where 60 and 80 animals were tested in each group. Ultrasonographic apparatus (Piglog 105) was used, and the anatomic locations were: fat thickness in the loin part (FT1), between 3rd and 4th lumbar 
vertebrae, $7 \mathrm{~cm}$ laterally to the back line; back fat thickness (FT2) between the 3rd and 4th rib, from the rear, $7 \mathrm{~cm}$ laterally to the back line and MLD depth, between $3 \mathrm{rd}$ and $4 \mathrm{th}$ rib from the rear, $7 \mathrm{~cm}$ laterally to the back line. Processing of data was done by implementation of adequate programme, i.e. use of the method of least squares (LSMLMW and MIXMDL-Harvey, 1990).

Traits were analised by following mixed model of the least squares:

$\mathrm{Y}_{\mathrm{ijklm}}=\mu+\mathrm{O}_{\mathrm{i}}+\mathrm{R}_{\mathrm{j}}+\mathrm{GR}_{\mathrm{k}}+\mathrm{GM}_{1}+\mathrm{e}_{\mathrm{ijklm}}$

in which: .

$\mathrm{Y}_{\mathrm{jjklm}}=$ demonstration of the trait of $\mathrm{m}$ - individual, daughter of $\mathrm{i}$ - sire, $\mathrm{j}$ race, born k- year and measured 1 - year; $\mu=$ overall mean, $\mathrm{O}_{\mathrm{i}}=$ random influence of i- sire, $R_{j}=$ fixed influence of $j$ - race, $G_{k}=$ fixed infuence of $k$ - year of birth, $G_{1}=$ fixed influence of 1 - year of measurement, eijklm= random error.

Coefficient of heritability Heritability $\left(\mathrm{h}^{2}\right)$ was calculated by the method of interclass correlation of halfsisters by sires through the following formula:

$$
h^{2}=4 \frac{\sigma_{b g s}^{2}}{\sigma_{b g s}^{2}+\sigma_{i g s}^{2}}
$$

where:

$\mathrm{h}^{2}=$ heritability, $\sigma_{b g s}^{2}=$ varians between gropus sires, $\sigma_{\text {igs }}^{2}=$ varians inside groups sires.

Genetic correlations show the connection between additive effects of genes which influenced on demonstration of two traits, and we calculated it by the formula:

$$
r_{G}=\frac{\operatorname{Cov}}{\sqrt{\sigma_{b g s}^{2} \times \sigma_{i g s}^{2}}}
$$

where:

$\mathrm{r}_{\mathrm{G}}=$ genetic correlation, $\mathrm{Cov}=$ covarians, $\sigma_{\text {bgs }}^{2}=$ varians between gropus sires, $\sigma_{i g s}^{2}=$ varians inside groups sires.

\section{Result and Discussion}

Heritability values and heritability errors for growth intensity and meat yield in performance test gilts during five year research (2007. to 2011.), are presented in table 1. Presented data show that the low heritability was established for the age at the end of test $\left(h^{2}=0.103\right)$ and life daily gain $\left(h^{2}=0.110\right)$. In regard to meat yield indicators, determined heritability values ranged from low to high, e.g. for MLD depth low heritability was established $\left(h^{2}=0.105\right)$, medium heritability value for FT1 $\left(h^{2}=0.461\right)$ and high for FT2 $\left(h^{2}=0.639\right)$ and lean percentage $\left(\mathrm{h}^{2}=0.633\right)$. 
Table 1. Heritability $\left(\mathrm{h}^{2}\right)$ and heritability errors $\left(\mathrm{Sh}^{2}\right)$ for growth intensity and meat yield indicators

\begin{tabular}{|l|c|c|}
\hline Traits & $\mathrm{h}^{2}$ & $\mathrm{Sh}^{2}$ \\
\hline Age at the end of test (AET), days & 0.103 & 0.033 \\
\hline Life daily gain (LDG), g & 0.110 & 0.035 \\
\hline FT1, mm & 0.461 & 0.104 \\
\hline FT2, mm & 0.639 & 0.134 \\
\hline MLD, mm & 0.105 & 0.033 \\
\hline Meat yield, \% & 0.633 & 0.133 \\
\hline
\end{tabular}

Phenotypic correlations for growth intensity traits and indicators of meat yield are presented in table 2. Obtained results for phenotypic correlations show that the correlation between FT1 and FT2 was strong $\left(r_{p}=0.638\right)$. Correlation between the fat thickness values (FT1 and FT2) and lean percentage was negative and very strong $\left(r_{p}=-0.880\right.$ and $\left.r_{p}=-0.895\right)$, whereas weak correlation $\left(r_{p}=0.332\right)$ was determined between MLD depth and \% of meat. After testing of the significance of correlations according to table values it was established that they were highly significant $(\mathrm{P}<0.01)$.

Table 2. Coefficients of phenotypic (rp) and genetic (rg) correlations for growth intensity and meat yield indicators

\begin{tabular}{|l|c|c|}
\hline Traits & $\mathrm{rp}$ & $\mathrm{rg}$ \\
\hline FT1 : FT2 & $0.638^{* *}$ & $0.930^{* *}$ \\
\hline FT1 : MLD & $-0.103^{* *}$ & $-0.653^{* *}$ \\
\hline FT1 : Meat yield & $-0.880^{* *}$ & $-0.979^{* *}$ \\
\hline FT1 : AET & $-0.027^{\mathrm{ns}}$ & $0.226^{* *}$ \\
\hline FT1 : LDG & $0.021^{\mathrm{ns}}$ & $-0.252^{* *}$ \\
\hline FT2 : MLD & $-0.216^{* *}$ & $-0.627^{* *}$ \\
\hline FT2 : Meat yield & $-0.895^{* *}$ & $-0.982^{* *}$ \\
\hline FT2 : AET & $-0.019^{\mathrm{ns}}$ & $0.267^{* *}$ \\
\hline FT2 : LDG & $0.013^{\mathrm{ns}}$ & $-0.292^{* *}$ \\
\hline MLD : Meat yield & $0.332^{* *}$ & $0.692^{* *}$ \\
\hline MLD : AET & $-0.015^{\mathrm{ns}}$ & $-0.167^{* *}$ \\
\hline MLD : LDG & $0.016^{\mathrm{ns}}$ & $0.171^{* *}$ \\
\hline Meat yield : AET & $0.023^{\mathrm{ns}}$ & $-0.262^{* *}$ \\
\hline Meat yield : LDG & $-0.016^{\mathrm{ns}}$ & $0.286^{* *}$ \\
\hline AET : LDG & $-0.994^{* *}$ & $-0.977^{* *}$ \\
\hline
\end{tabular}

Genetic correlations for traits of growth intensity and indicators of meat yield are presented in table 2. Based on presented data it is apparent that the level of dependance between FT1 and FT2 full/complete $\left(r_{\mathrm{g}}=0.930\right)$. Correlation 
between back fat thickness (FT1 and FT2) and depth of MLD was negative and strong $\left(r_{\mathrm{g}}=-0.653\right.$ and $\left.\mathrm{r}_{\mathrm{g}}=-0.627\right)$. Negative and full/complete correlation between back fat thickness (FT1 and FT2) and lean percentage $\left(\mathrm{r}_{\mathrm{g}}=-0.979 \mathrm{i}_{\mathrm{g}}=-0.982\right)$, and strong correlation between MLD depth and \% of meat $\left(\mathrm{r}_{\mathrm{g}}=0.692\right)$ were established. For genetic correlations, after testing of significance of said traits, it was established that they were statistically highly significant $(\mathrm{P}<0.01)$, so it can be concluded that there was full/complete and strong correlation between indicators of meat yield.

Results of this research were in concordance with heritability values (Table 1) for daily gain established by Groeneveld and Peškovičova (1999) and Petrović et al. (2002) of 0.13 to 0.19 . Compared to our study, slightly higher heritability values for AET in the range from 0.26 to 0.32 were established by Li and Kennedy (1994) and Groeneveld et al., (1996). Also, Dufek and Buchta (1987) have established high heritability values for LDG in Large Yorkshire and Landrace $\left(\mathrm{h}^{2}=0.728\right.$ and 0.643 , respectively). Our study was in concordance with results obtained by Ducos et al. (1993), Li and Kennedy (1994) and Tomka et al. (2010) who have established $h^{2}$ values for back fat thickness of 0.46 to 0.64 . Lower $h^{2}$ values for FT1 and FT2 have been established by Petrović et al. (2002) and Apostolov (2009) of 0.18 to 0.44 . Results of our study in regard to meat yield are in concordance with results of Ducos et al. (1993) who have established heritability value of 0.60 to 0.65 for French Large Yorkshire and Landrace, as well as results of Groeneveld et al. (1996) who have established in Hungarian population of large Yorkshire and Landrace heritability values of 0.66 and 0.62 . Slightly lower heritability coefficients for carcass lean percentage has been established by Petrović et al. (2002) and Radović et al. (2003), of 0.560 and 0.502. Contrary to our research, Groeneveld et al. (1998) have established lower heritability values for $\%$ of meat (established using apparatus PIGLOG 105) of 0.25 to 0.36 and for $\%$ of meat (determined by dissection) in the range from 0.25 to 0.39 . Szyndler-Nędza et al. (2010) have established for gilts of Polish large Yorkshire and Polish Landrace breeds lower heritability values $\mathrm{h}^{2}$ for back fat thickness $(0.117$ to 0.169$)$ and share of meat (0.097 to 0.185) compared to present results. Heritability values established for MLD depth in animals of Polish Landrace breed (0.105:0.158) were in concordance with our results, whereas for Polish Large Yorkshire breed significantly lower $\mathrm{h}^{2}$ value was established (0.045).

Results of our study are in concordance with studies conducted by numerous authors who have established between back fat thickness and daily gain very strong and weak genetic and phenotypic correlations (Bereskin and Frobish, 1982; Dufek and Buchta, 1987; Skorupski et al., 1996; Senčić et al., 1999). Also, in concordance with our results, Dufek and Buchta (1987) and Li and Kennedy (1994) have established very strong and weak phenotypic and genetic correlations between back fat thickness and AET, in the range from -0.04 to -0.12 for phenotypic, and from -0.06 to -0.17 for genetic correlations. Suzuki et al. (2005) have established weak genetic correlation between daily gain (of 30-105 kg) and 
back fat thickness measured in the centre of the back $\left(\mathrm{r}_{\mathrm{g}}=0,34\right)$, whereas in present study very weak negative correlation between fat thickness (FT2) and LDG $\left(\mathrm{r}_{\mathrm{g}}=-\right.$ 0.292) was established. In the research by Sonessona et al. (1998), less strong negative correlation was established $\left(\mathrm{r}_{\mathrm{g}}=-0,77\right)$ between back fat thickness and meat yield compared to present result $\left(\mathrm{r}_{\mathrm{g}}=-0,98\right)$. Apostolov (2009) indicates less strong negative correlations between FT1 and share of meat $r_{p}=-0.658$ and $r_{g}=-$ 0.723 compared to results obtained in the present study. In said research, differences established for correlation between FT2 and share of meat, in comparison to present study, were lower $\left(r_{p}=-0.789: r_{P}=-0.895\right.$ i $r_{g}=-0,928: r_{g}=-$ 0.982).

\section{Conclusions}

Based on these results we can conclude that the degree of heritability for age and daily gain is slightly lower than the results of other authors, which can be explained by the fact that the tests were performed on different breeds and swine herds, as well as that different models were applied, and different fixed and random factors included. Heritability values for fat thickness and meat yield show that these traits have high level of heritability and are transfered to the progeny, whereas the level and strength of their dependance show that by decreasing the fat thickness positive influences is exhibited on meat yield, and that by increasing of depth of MLD also the meat yield is increased.

\section{Acknowledgements:}

Research was financed by the Ministry of Education, Science and Technological Development of Republic of Serbia, project TR 31081.

\section{Heritabilitet, fenotipske i genetske korelacije intenziteta porasta i mesnatosti svinja}

Č. Radović, M. Petrović, B. Živković, D. Radojković, N. Parunović, N. Brkić, N. Delić

\section{Rezime}

Petogodišnjim istraživanjem su bila obuhvaćena dva genotipa nazimica švedski landras i melezi $F_{1}$ generacije ŠLxVJ. Od ukupnog broja $(n=3600)$ istraživanjem je obuhvaćeno 1709 grla genotipa ŠL i 1891 grla genotipa ŠLxVJ. Merenje debljine leđne slanine i dubine musculus longissimus dorsi (MLD) i procena mesnatosti je obavljeno ultrazvučnim aparatom Piglog 105. Za pokazatelje mesnatosti utvrđeni 
su srednji heritabiliteti za SL1 $\mathrm{h}^{2}=0,461$, a visoki za SL2 $\mathrm{h}^{2}=0,639$, i za mesnatost $\mathrm{h}^{2}=0,633$. Nizak heritabilitet utvrđen je za dubinu MLD-a $\left(\mathrm{h}^{2}=0,105\right)$, životni dnevni prirast $\left(h^{2}=0,110\right)$ i za uzrast $\left(h^{2}=0,103\right)$. Utvrđene fenotipske korelacije između debljine slanine SL1 i SL2 su jake $\left(r_{p}=0,638\right)$; između debljine slanine $i$ mesnatosti korelacije su vrlo jake $\left(\mathrm{r}_{\mathrm{p}}=-0,880\right.$ do $\left.-0,895\right)$, dok su između debljine slanine i MLD-a jako slabe i negativne $\left(r_{\mathrm{g}}=-0,103\right.$ do $\left.-0,216\right)$. Genetske korelacije su jače od fenotipskih, tako da je između debljine slanine korelacija potpuna $\left(r_{\mathrm{g}}=0,930\right)$, kao i između debljine slanine i mesnatosti $\left(\mathrm{r}_{\mathrm{g}}=-0,979\right.$ do $\left.-0,982\right)$, dok je korelacija jaka i negativna između debljine slanine i MLD-a $\left(\mathrm{r}_{\mathrm{g}}=-0,627\right.$ do $\left.-0,653\right)$.

\section{References}

APOSTOLOV A. (2009): Evaluation of some more important phenotypic and genetic parameters of the performance traits of small populations from the Danube White breed. Bulgarian Journal of Animal Science, 15, 471-474.

BERESKIN B., FROBISH L. T. (1982): Carcass and related traits in Duroc and Yorkshire pigs selected for sow productivity and pig performance. Journal of Animal Science, 55, 554-564.

CHAN D. E., WALKER N. P., MILLS W. E. (2002): Prediction of Pork Quality Characteristics Using Visible and Near-Infrared Spectroscopy. Transactions of the ASAE, 45, 5, 1519-1527.

DUCOS A., BIDANEL J. P., DUCROCQ V., BOICHARD D., GROENEVELD E. (1993): Multivariate restricted maximum likelihood estimation of genetic parameters for growth, carcass and meat quality traits in French Large White and French Landrace pigs. Genetics Selelection Evolution, 25, 5, 475-493.

DUFEK J., BUCHTA S. (1987): Biometric analysis of the production and reproduction characteristics of pigs kept in the elite herds in the Czech Socialist Republic and the deretmination of selection indices. Scientia Agriculture Bohemoslovaca, 19, 3, 179-190.

GORJANC G., MALOVRH Š., KOVAČ M., GLAVAČ-VNUK M., ZRIM J. (2003): Proučavanje možnosti vključivte klavnih lastnosti v napoved plemenske vrednosti pri prašičih. Zbornik Biotehniške Fakultete Univerze v Ljubljani, Kmetijstvo Zootehnika, 82, 2, 89-96.

GROENEVELD E., CSATO L., FARKAS J., RADNOCZI L. (1996): Joint genetic evaluation of field and station test in the Hungarian Large White and Landrace populations. Archiv für Tierzucht, 39, 5, 513-531.

GROENEVELD E., WOLF J., WOLFOVA M., JELINKOVA V., VECEROVA D. (1998): Estimation of genetic parameters for Czech pig breeds using a multitrait animal model. Zuchtungskunde, 70, 2, 96-107.

GROENEVELD E., PEŠKOVIČOVA D. (1999): Simultaneous estimation of the covariance structure of field and station test traits in Slovakian pig populations. Czech Journal of Animal Science, 44, 145-150.

HARVEY R.W. (1990): User's guide for LSMLMW and MIXMDL. Ver. PC-2, 1-91. 
HERMESCH S., LUXFORD B.G., GRASER H.U. (2000): Genetic parameters for lean meat yield, meat quality, reproduction and feed effciency traits for Australian pigs. 1. Description of traits and heritability estimates. Livestock Production Science, 65, 239-248.

KNAPP P., WILLAM A., SÖLKNER J. (1997): Genetic parameters for lean meat content and meat quality traits in different pig breeds. Livestock Production Science, 52, 69-73.

LI X. W., KENNEDY B. W. (1994): Genetic parameters for growth rate and backfat in Canadian Yorkshire, Landrace, Duroc and Hampshire pigs. Journal of Animal Science, 72, 1450-1454.

LO L. L., MCLAREN G. D., MCKEITH K. F., FERNANDO L. R., NOVAKOFSKI J. (1992): Genetic Analyses of Growth, Real-Time Ultrasound, Carcass, and Pork Quality Traits in Duroc and Landrace Pigs: II. Heritabilities and Correlations. Journal of Animal Science, 70, 2387-2396.

PETROVIĆ M., RADOJKOVIĆ D., ROMIĆ D., PUŠIĆ M., MIJATOVIĆ M., BRKIĆ N. (2002): Genetska i fenotipska varijabilnost osobina performans testiranih nerastova i nazimica. Biotechnology in Animal Husbandry, 18, 5-6, 67-72. PETROVIĆ M., PUŠIĆ M., RADOJKOVIĆ D., MIJATOVIĆ M., RADOVIĆ Č., ŽIVKOVIĆ B. (2006): Fenotipska i genetska varijabilnost osobina kvaliteta polutki i mesa. Biotechnology in Animal Husbandry, 22, 5-6, 1-10.

RADOVIĆ Č., PETROVIĆ M., JOSIPOVIĆ S., ŽIVKOVIĆ B., KOSOVAC O., FABJAN M. (2003): Uticaj različitih genotipova, očeva i sezone klanja na klanične osobine svinja. Biotechnology in Animal Husbandry, 19, 1-2, 11-16.

SENČIĆ D., ANTUNOVIĆ Z., PERKOVIĆ A. (1999): Expression of Large White young boars fattening in a performance test. Czech Journal of Animal Science, 44, $55-59$.

SKORUPSKI M. T., GARRICK D. J., BLAIR H. T. (1996): Estimates of genetic parameters for production and reproduction traits in three breeds of pigs. New Zealand Journal of Agricultural Research, 39, 3, 387- 395.

SONESSON K. A., DE GREEF H. K., MEUWISSEN E. T. H. (1998): Genetic parameters and trends of meat quality, carcass composition and performance traits in two selected lines of large white pigs. Livestock Production Science, 57, 23-32.

SUZUKI K., KADOWAKI H., SHIBATA T., UCHIDA H., NISHIDA A. (2005): Selection for daily gain, loin-eye area, backfat thickness and intramuscular fat based on desired gains over seven generations of Duroc pigs. Livestock Production Science, 97, 193-202.

SZYNDLER-NĘDZA M., TYRA M., RÓZYCKI M. (2010): Coefficients of heritability for fattening and slaughter traits included in a modified performance testing method. Annals of Animal Science, 10, 117-125.

TOMKA J., PEŠKOVICOVÁ D., KRUPA E., DEMO P. (2010): Genetic analysis of production traits in pigs measured at test stations. Slovak Journal of Animal Science, 43, 2, 67 - 71. 